\title{
PREVALENCE OF CANDIDA SPECIES IN UMBILICAL CATHETERS IMPLANTED IN NEWBORNS IN NATAL, BRAZIL
}

\author{
Ana Cristina Santos Fernandes ${ }^{1}$; Francisco Canindé de Sousa Junior ${ }^{2}$; Solange Maria de Oliveira ${ }^{3}$; Lucia Calich ${ }^{4}$; \\ Eveline Pipolo Milan ${ }^{5 *}$
}

${ }^{1}$ Biochemical pharmacist; ${ }^{2}$ Graduating in Clinical Analyses and scholarship holder in PIBIC scientific initiation, Universidade Federal do Rio Grande do Norte (UFRN); ${ }^{3}$ Microbiologist, HOSPED Microbiology Laboratory, UFRN; ${ }^{4}$ SCIH Coordinator, Januário Cicco Maternity School, UFRN; ${ }^{5}$ Adjunct Professor, Department of Infectology, UFRN, Natal, Brazil

Submitted: May 04, 2006; Returned to authors for corrections: September 04, 2006; Approved: January 18, 2007

\begin{abstract}
All the newborns with umbilical venous catheters, hospitalized in the neonatal intensive care unit at Januário Cicco Maternity Hospital in Natal, Brazil, between January, 2003 and December, 2004 were studied. The prevalence of Candida species in the tips of intra-venous catheters was assessed, as well as the coexisting exposures that the patients were subjected to. Catheter tips were cultivated in blood agar and when yeast culture occurred, the colony was subcultivated for species identification through morphologic and biochemical assays. From a total of 240 catheters, 41 were positive for yeasts, and 34 were submitted to identification. The following agents were isolated: 13 C. albicans (38\%), 10 Candida parapsilosis (29\%), 8 C. tropicalis (20\%), one C. guilliermondii (3\%), one C. famata (3\%) and one Trichosporon spp. (3\%). Three patients among those with positive catheter tip fungal cultures were also hemoculture positive, with the same fungal species at both sites. Among the coexisting exposures, it should be pointed out that all the patients underwent broad spectrum antibiotic therapy, used a nasogastric probe, in addition to undergoing other invasive procedures such as mechanical ventilation and umbilical catheter implantation.
\end{abstract}

Key words: Fungemia; Candida; catheterization, central venous; newborn

\section{INTRODUCTION}

Sepsis is common in low birth weight newborns in neonatal intensive care units (NICU) and is mainly the result of catheter use (12).

The frequency of fungemia in newborns and the variability of species involved have increased in the last decade $(19,20)$. Although C. albicans is the predominant species in the majority of intensive care units, recent reports indicate an increase in sepsis cases caused by non-albicans Candida species (10).

The insertion point of the catheter is considered the main entry port for sepsis-causing microorganisms (5), which grow on the external part of the catheter, penetrating the blood stream through the intravascular portion $(8,14)$. However, invasion from the catheter occurs less frequently through the use of contaminated intravenous fluids, from fungemia and from the central portion of the catheter (13).

The relation between fungal colonization and invasive disease has been widely studied (6). Baley et al (2) observed that $26.7 \%$ of low birth weight newborns were colonized by Candida and $7.7 \%$ developed invasive disease. Low hemoculture positivity for fungi is an important obstacle to fungemia diagnosis. Only 40 to $60 \%$ of fungemia cases are associated with positive hemoculture (20).

The aim of this study was to analyze the prevalence of Candida species in the tips of intravenous catheters in newborns and assess the coexisting exposures that the patients were submitted to.

*Corresponding Author. Mailing address: Av. Alexandrino de Alencar, 1384 apto 500 - Ed. Bosque dos Namorados - Tirol - 59015-350 - Natal - RN. Tel.: (84) 32015747. E-mail: eve@ufrnet.br 


\section{MATERIALAND METHODS}

From January, 2003 to December, 2004, 268 newborns with umbilical venous catheters, hospitalized in the NICU of Januário Cicco Maternity School (MEJC) were recruited. Material collection consisted of the medically indicated removal of the umbilical catheter. The catheter was sent to the microbiology laboratory at UFRN Children's Hospital, where semiquantitative culture technique was performed in blood agar medium. When yeast cultures appeared, they were reisolated on CHROMagar Candida ${ }^{\circledR}$ plate. Briefly, after performing germ tube test, negative isolates were submitted to microscopic morphology observation on cornmeal-Tween 80 agar, and carbohydrate fermentation and assimilation comprising 5 and 15 sugars, respectively. If necessary, organisms were also checked for urease production, nitrate assimilation, and ascospore formation. C. albicans identification by germ tube test was confirmed by the presence of chlamidoconidia on cornmeal-Tween 80 agar and differentiated from $C$. dubliniensis by the ability to growth at $42^{\circ} \mathrm{C}$ and $45^{\circ} \mathrm{C}$ and capacity to growth on hypertonic Sabouraud broth $(1,7,17)$

\section{RESULTS AND DISCUSSION}

Between January, 2003 and December, 2004, 1922 newborns, of which 268 had umbilical catheters, were admitted to the MEJC Neonatal NICU. Only 240 catheters were submitted to microbiological analysis. Of these, 140 had negative cultures and 59 had positive bacterial cultures; however, in 6 cases the bacterial population was mixed, with 2 distinct bacteria species growing in the same culture. The culture was positive for fungi (Tab. 1) in 41/240 catheters (17\%), but only 34 of these were sent for identification, with the following results: C. albicans, 13 (38\%), C. parapsilosis, 10 (29\%), C. tropicalis, 8 (24\%), C. guilliermondii, 1 (3\%), C. famata, 1 (3\%) and Trichosporon spp., 1 (3\%) (Fig. 1). Positive hemocultures for the same species, were found in three of the 34 newborns, confirming in these cases, a diagnosis of fungemia. These findings are compatible with those reported in the literature. Pfaller et al (9), in a study performed in the USA, Canada and South America, demonstrated 306 candidemia episodes in 34 medical centers. Of the cases reported, $50 \%$ occurred in patients hospitalized in NICUs, in which C. albicans was responsible for $53.3 \%$ of the blood infections, followed by C. parapsilosis (15.7\%), C. glabrata (15\%), C. tropicalis (7.8\%), C. krusei (2\%), C. guilliermondii (0.7\%) and Candida spp. (5.8\%).

In 1987, Stotter et al (16) reported the use of a shield around the tip of the catheter as standard intervention for minimizing exposure of the lumen to microorganisms. The authors observed that the incidence of infections related to catheter use fell from $39 \%$ to $8 \%$. Sandstedt (14) described another study where a heated catheter tip was used, resulting in catheter sepsis rate of only $0.95 \%$.
Table 1. Microbiological assessment of 240 umbilical catheters implanted in newborns hospitalized at the MEJC Neonatal ICU between January, 2003 and December, 2004.

\begin{tabular}{|c|c|c|c|c|c|c|c|}
\hline \multirow{3}{*}{ Year } & \multicolumn{6}{|c|}{ Umbi lical catheter culture results } & \multirow{3}{*}{ Total } \\
\hline & \multicolumn{2}{|c|}{ Yeast } & \multicolumn{2}{|c|}{ Bacteria } & \multicolumn{2}{|c|}{ Negative } & \\
\hline & $\mathrm{N}$ & $\%$ & $\mathrm{~N}$ & $\%$ & $\mathrm{~N}$ & $\%$ & \\
\hline 2003 & 24 & 22 & 29 & 27 & 55 & 51 & 108 \\
\hline 2004 & 17 & 13 & 35 & 25 & 85 & 62 & 137 \\
\hline Total & 41 & 17 & 64 & 26 & 140 & 57 & $245^{*}$ \\
\hline
\end{tabular}

* Multiple culture were found in 6 samples.

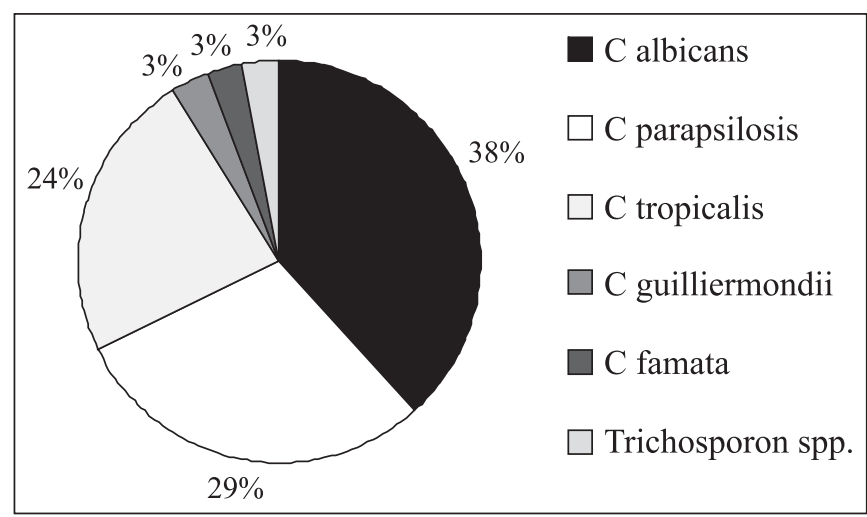

Figure 1. Distribution of fungal species isolated from 34 umbilical catheters implanted in newborns hospitalized at MEJC Neonatal ICU between January, 2003 and December, 2004.

In this study, approximately $43 \%$ of the 240 catheters analyzed over the 26-month period were positive for some type of organism, with bacteria and yeast isolated in $26 \%$ and $17 \%$ of the umbilical catheters, respectively. The semiquantitative culture has some limitations, because it only evaluates the microorganisms attached to the external part of the catheter, and may not detect episodes inside the lumem or in the initial state. Furthermore, it prevents the entire surface of the catheters from touching the agar when they are curved (15).

With respect to coexisting exposures analysis, it was observed that the 34 newborns (100\%) with fungal growth in catheter culture were treated with broad-spectrum antibiotic therapy simultaneously and $24(70.6 \%)$ obtained first or second Apgar scores less than or equal to 7 . All the newborns received some form of artificial ventilation, distributed thusly: $18(53 \%)$ were given mechanical ventilation, 16 (47\%) CPAP, $3(7.3 \%) \mathrm{O}_{2}$ under pressure (Hood). An orogastric probe was used in 25 newborns $(73 \%)$ and $29(85 \%)$ were premature. The mean birth weight of the 34 newborns was $1,519 \mathrm{~g}$, ranging from $650 \mathrm{~g}$ to 
$4,480 \mathrm{~g}$; 6 of them (18\%) had low birth weight (between $1,000$ and $1,500 \mathrm{~g})$ and $16(47 \%)$ extremely low birth weight (under 1,000g) (Tab. 2). In the newborn of this project, the time elapsed between CVC insertion and positive culture was between 5 and 36 days, with a mean of 15 days and median of 13 days. Mean NICU stay was 19 days. Death occurred in 9 of the 34 cases (26\%). According to the literature, neonatal sepsis is a common event in low birth weight newborns, with the majority of episodes catheter-related $(12,18)$. Rowen et al. (11) assessed 98 isolates from 17 institutions. The mean gestational age of the patients was 26 weeks, mean newborn weight $820 \mathrm{~g}$, mean hospital stay 24 days and the species isolated were: C. albicans $56 \%$, C. parapsilosis 34\%, C. tropicalis $5.3 \%$ and Candida spp $4.7 \%$. Twenty-nine newborns $(85 \%)$ with gestational age under 37 weeks were diagnosed as premature. Only $5(15 \%)$ were born at term, with gestational age greater than 37.1 weeks.

The antibiotics most frequently used in the 34 newborns studied were crystalline penicillin, amikacin and cefotaxime. It is important to consider that $100 \%$ of the patients received broad-spectrum antibiotic therapy with two or more antibiotics simultaneously and the preferred treatment in suspected cases of sepsis was the simultaneous administration of crystalline penicillin and amikacin.

The most relevant coexisting exposures found were similar to those reported by other centers: broad-spectrum antibiotic therapy, use of umbilical catheter (inclusion factor in this study), use of enteral and/or parenteral probe and artificial ventilation.

The hypothesis that catheter tip contamination preceded bacteremia or fungemia needs to be verified. For this, the microorganism inside the catheter tip must be investigated and isolated concomitantly from hemocultures. In the study performed at the MEJC Neonatal NICU, only 3 cases of fungemia with positive hemocultures for yeast were reported among the 34 newborns with catheters colonized with fungi. It must be emphasized that there is low sensitivity of the hemoculture to fungi when this is performed using the traditional technique $(3,4)$, which is practiced in the majority of public laboratories in Natal, Brazil, including the MEJC Microbiology Laboratory.

In this study, 9 (26\%) of the 34 cases resulted in death; of these, 7 (78\%) had extremely low birth weight (ELBW), 8 (89\%) were premature and all had mean NICU stay in excess of 12 days. The species isolated in these patients were $C$. albicans, 5 (56\%), C. tropicalis, 3 (33\%) and C. parapsilosis, 1 (11\%).

The isolation of yeasts is frequent in central venous catheters at MEJC Neonatal NICU, occurring in $17 \%$ of all the catheters analyzed. The most frequently isolated agents were C. albicans $(38 \%)$ and C. parapsilosis $(29 \%)$. The main coexisting exposure for fungi colonization of the catheter was the use of broad spectrum antibiotic therapy. The elevated mortality rate $(26 \%)$ in patients with catheter culture positive for fungi suggests that this factor must contribute to the worsened prognosis of these patients; however, this finding requires more detailed analysis. Finally, the study calls attention to the systemic occurrence of fungal infections in neonatal intensive care units in Natal, Brazil.

\section{ACKNOWLEDGMENTS}

This study was financed in part by CNPq and Propesq/ UFRN (scientific initiation scholarships)

\section{RESUMO}

\section{Incidência de espécies de Candida em cateteres umbilicais implantados em recém-nascidos em Natal-RN}

Foram estudados, entre janeiro de 2003 a dezembro de 2004 , todos os recém-nascidos internados na UTI neonatal da Maternidade Escola Januário Cicco, portadores de cateter venoso umbilical. Avaliou-se a prevalência de espécies de Candida nas pontas de cateteres intra-venosos dos neonatos, e os fatores associados a que os pacientes estavam submetidos. As pontas de cateter foram cultivadas em ágar sangue, e, 
quando houve crescimento de colônia leveduriforme, esta foi subcultivada para a realização de provas morfológicas e bioquímicas para identificar a espécie. Do total de 240 cateteres analisados, 41 apresentaram crescimento de leveduras, sendo 34 encaminhados para identificação, observando-se os seguintes agentes: 13 C. albicans (38\%), 10 Candida parapsilosis (29\%), 8 C. tropicalis (20\%), 1 C. guilliermondii (3\%), 1 C. famata (3\%) e 1 Trichosporon spp. (3\%). Dos pacientes que apresentaram cultura de ponta de cateter positiva para fungos, três tiveram hemocultura positiva com a mesma espécie em ambos os sítios. Entre os fatores de risco destaca-se que todos os pacientes faziam uso de antibioticoterapia de amplo espectro, portavam sonda nasogástrica, além de outros procedimentos invasivos, como ventilação mecânica e cateter umbilical.

Palavras-chave: Fungemia, Candida, cateterismo venoso central, recém-nascido

\section{REFERENCES}

1. Alves, S.H.; Milan, E.P.; Santana, P.L.; Oliveira, L.O.; Janio, M.; Colombo, A.L. (2002). Hypertonic sabouraud broth as a simple and powerful test for Candida dubliniensis screening. Diagn. Microbiol. Infect. Dis., 43(1), 85-86.

2. Baley, J.E.; Kliegman, R.M.; Boxerbaum, B.; Fanaroff, A.A. (1986). Fungal colonization in very low birth weight infants. Pediatrics., 78(2), 225-325.

3. Bodey, G.P.; Anaissie, J.; Edwards, J.E. (1993). Definitions of Candida infections. In: Bodey, G.P (ed). Candidiasis: Pathogenesis, Diagnosis, and Treatment. Raven Press Ltd., New York, USA, p.407-408.

4. Calderone, R.A. (2002). Candidemia. In: Calderone, R.A. (ed). Candida and Candidiasis. ASM Press, Washington, USA, p.327340.

5. Capell, S.; Linares, J.; Sitges-Serra, A. (1986). Catheter sepsis due to coagulase-negative staphylococci in patients on total parenteral nutrition. Eur. J. Clin. Microbiol., 5(1), 40-42.

6. Jarvis, W.R. (1995). Epidemiology of nosocomial fungal infections, with emphasis on Candida species. Clin. Infect. Dis., 20(6), 15261530.

7. Kurtzman, C.P.; Fell, J.W. (1998). The yeasts, a taxonomic study. Elsevier Science Publishers, Amsterdam, Netherlands.
8. Mermel, L. (2000). Prevention of intravascular catheter-related infections. Ann Intern Med., 132(5), 391-402.

9. Pfaller, M.A.; Jones, R.N.; Doem, G.V.; Kluger, G. (1998). International Surveillance of Bloodstream Infections due to Candida Species: Frequency of occurrence and antifungal susceptibilities of isolates collected in 1997 in the United States, Canada, and South America for the SENTRY Program. J. Clin. Microbiol., 36(7), 1886-1889.

10. Rangel-Frausto, M.S.; Houston, A.K.; Bale, M.J.; Fu, C.; Wenzel, R.P. (1994). An experimental model for study of Candida survival and transmission in human volunteers. Eur. J. Clin. Microbiol. Infect. Dis., 13(7), 590-595.

11. Rowen, J.L.; Tate. J.M.; Nordoff, N.; Passarell, L.; McGinnis, M.R. (1999). Candida isolates from neonates: frequency of misidentification and reduced fluconazole susceptibility. J. Clin. Microbiol., 37(11), 3735-3737.

12. Sadiq, H.F.; Devaskar, S.; Keenan, W.J.; Weber, T.R. (1987). Broviac catheterization in low birth weight infants: incidence and treatment of associated complications. Crit. Care Med., 15(1), 47-50.

13. Salzman, M.B.; Isenberg, H.D.; Shapiro, J.F., Lipsitz, P.J.; Rubin, L.G. (1993). A prospective study of the catheter hub as the portal of entry for microrganisms causing catheter-related sepsis in neonates. J. Infect. Dis., 167(2), 487-490.

14. Sandstedt, S.; Hesselvik, F.; Marklund, T.; Stemport, G. (1989). Percutaneous, tunelled silicone elastomer central venous catheters for total parenteral nutrition: low sepsis and thrombosis rate. A prospective study of 315 catheters. Nutrition., 5(1), 23-26.

15. Soloaga, R.; Tokumoto, M.; Fernandez, A.; Nagel, C.; Gutfraind, Z.; Procopio, A. (2000). The microbiology laboratory in the diagnosis of bacteremia associated with catheters. Enferm Infecc Microbiol Clin., 18(2), 62-65

16. Stotter, A.T.; Ward, H.; Waterfield, A.H.; Hilton, J.; Sim, A.J. (1987) Junctional care: the key to prevention of catheter sepsis in intravenous feeding. J. Parenter. Enteral. Nutr., 11(2), 159-162.

17. Tintelnot, K.; Haase, G.; Seibold, M.; Bergmann, F.; Staemmler, M.; Franz, T.; Naumann, T. (2000). Evaluation of phenotypic markers for selection and identification of C. dublinienses. J. Clin. Microbiol., 38(4), 1599-1608.

18. Warner, B.W.; Gorgore, P.; Schilling, S.; Farrell, M.; Ghory, M.J. (1987). Multiple purpose central venous access in infants less than 1,000 grams. J. Pediatr. Surg., 22(9), 820-822.

19. Weinberger, M.; Sacks, T.; Sulkes. J.; Shapiro, M.; Polacheck, I. (1997). Increasing fungal isolation from clinical specimens: experience in a university hospital over a decade. J. Hosp. Infect., 35(3), 185-195.

20. Wright, W.L.; Wenzel. R.P. (1997). Nosocomial Candida. Epidemiology, transmission, and prevention. Infect. Dis. Clin. North Am., 11(2), 411-425. 